IZA DP No. 6263

Development and Sources of Labor Productivity in Chinese Provinces

Biwei Su

Almas Heshmati

December 2011 


\title{
Development and Sources of Labor Productivity in Chinese Provinces
}

\author{
Biwei Su \\ Korea University \\ Almas Heshmati \\ Korea University \\ and IZA

\section{Discussion Paper No. 6263 \\ December 2011} \\ IZA \\ P.O. Box 7240 \\ 53072 Bonn \\ Germany \\ Phone: +49-228-3894-0 \\ Fax: +49-228-3894-180 \\ E-mail: iza@iza.org
}

\begin{abstract}
Any opinions expressed here are those of the author(s) and not those of IZA. Research published in this series may include views on policy, but the institute itself takes no institutional policy positions.

The Institute for the Study of Labor (IZA) in Bonn is a local and virtual international research center and a place of communication between science, politics and business. IZA is an independent nonprofit organization supported by Deutsche Post Foundation. The center is associated with the University of Bonn and offers a stimulating research environment through its international network, workshops and conferences, data service, project support, research visits and doctoral program. IZA engages in (i) original and internationally competitive research in all fields of labor economics, (ii) development of policy concepts, and (iii) dissemination of research results and concepts to the interested public.
\end{abstract}

IZA Discussion Papers often represent preliminary work and are circulated to encourage discussion. Citation of such a paper should account for its provisional character. A revised version may be available directly from the author. 
IZA Discussion Paper No. 6263

December 2011

\title{
ABSTRACT
}

\section{Development and Sources of Labor Productivity in Chinese Provinces}

\begin{abstract}
As China exhibited unprecedented rapid economic growth ever since its reform and openness, the development and sources of labor productivity has gradually come to the forefront. This paper studies the development and the source of labor productivity in 31 Chinese provinces during the period of 2000-2009. The labor productivity is investigated through an examination at both the levels and the growth rate. Particularly, we first look at the production function relationship, to see the contribution of labor and other production factors to the gross domestic product. Then, a number of possible determinants are defined. They are regressed on the level and the growth rate of labor productivity to shed light on their relationships. Controlled for unobserved time-specific and province-specific effects, the fixed effects model with heteroskedasticity robust adjustments have been used for the estimation of three functions. Regional breakdown shows severe disparity in the economy where three municipal cities have the highest labor productivity among other regions. Subsequently, we summarize the different sources and their contributions to labor productivity and provide several policy suggestions.
\end{abstract}

JEL Classification: $\quad$ C23, J24, R23, O15

Keywords: development, labor productivity, labor productivity growth, provinces, China

Corresponding author:

Almas Heshmati

Department of Food and Resource Economics

College of Life Science and Biotechnology

Korea University, East Building Room\#217

Anam-dong, Seongbuk-gu

Seoul 136-713

Korea

E-mail: heshmati@korea.ac.kr 


\section{Introduction}

Ever since the decay of the centrally planned economy, China has stunned the world with its high pace in economic growth and development. This is evident by the high annual average growth rate of nearly 9.7\% during the last three decades from 1978 to 2007 (Yang and Lahr, 2008). In 2010, according to the World Bank, its total GDP has surpassed Japan. It has ranked as the second largest economy of the world. This remarkable growth has also led to an increasing number of studies investigating the different aspects of China's economic growth (Chen and Feng, 2000; Wang and Yao, 2003; Yi, Fan and Li 2003; among others).

Developments in this area have been particularly focused on human capital issues. The neoclassical theory (Solow, 1957) points that human capital as the major source of the economic growth. This issue has been investigated in numerous studies (Romer, 1990; Becker, Murphy and Tamura, 1994; Benhabib and Spiegel, 1994). Nevertheless many studies of the human capital in China (Wang and Yao, 2003; Yue and Liu, 2006; Wong, 2006) illustrated the importance of human capital accumulation, the structural reform of the labor market and the effects of labor migration, etc. Few pieces of research examines the qualitative dimension of the human capital, say the labor productivity. This paper attempts to fill the gap in the existing literature by investigating the determinants of economic growth and in particular how these determinants affect the level and development of the labor productivity over time. In addition, we also study the causal factors and heterogeneity of the labor productivity across the Chinese provinces and compare the disparity between the regions.

By the OECD definition, the level of labor productivity is the ratio of a volume measure of output to a volume measure of the labor input. Volume measures of output are normally gross domestic product or gross value added. The two most generally used measures of input are working hours and the number of people in employment. In this paper, we define labor productivity as the ratio of the real GDP to the total labor force in each province. Several determinants are chosen based on the previous studies, and the list includes total investment in the fixed assets, total business volume of post and telecommunication, investment in education, average wage per employee, enterprises profit per employee, urban labor share of the total labor force, industry share to the economy, and female participation.

Methodologically, we apply fixed effects panel data multiple regression function model using provincial data over a period of 2000-2009. The benefits of using this panel data approach are obvious. It allows controlling for unobserved time and provincial heterogeneity effects to get more effective and consistent estimated coefficients. On the other hand, the panel data is much more informative. It featured with providing more variability, more degree of freedom and less co linearity among the variables. (Hsiao, 2003; and Baltagi, 2008).

This paper contributes to the measurement of the contribution of labor towards the economic growth in China. It improves our understanding of labor productivity and it 
enhances our knowledge on variations in the provincial development attributed to the difference in labor productivity. Information on the differences in the provincial labor productivity is important for the government to formulate policies for allocation and redistribution of productive resources. This information is also necessary to reduce the growing regional inequality in China. This is considered as one the important negative outcomes due to the country's rapid growth.

The following section provides a background of the Chinese economy and its labor market. Section 3 shows an overview of the literature on the determinants of the labor productivity. Data and models are described in section 4 and section 5 . Section 6 provides an analysis of the empirical results. Finally, section 7 concludes and gives some policy suggestions.

\section{The Chinese Economy}

Despite amazing development, China's economy has sent out mixed signals in the past 15 years. Figure 1 illustrates the World Bank statistics of China's growth rate for the period of 1996 to 2010. The average growth rate has been around 9.8\%. It went down from $10 \%$ in 1996/97 in relation with Asian financial crisis, but this decrease halted at $7.6 \%$ in 1999 . It gradually rose back to $10 \%$ again. The following 3 years showed an overheating economy reaching to $14.2 \%$ in 2007 . It was not until 2008 , when it was affected by the global economy crisis, the economy faced a significant downturn. The 4.6\% decrease made a departure disappearance from the double-digit growth rate that this country had been accustomed to for a year. Thereafter, the growth rate took about two years to climb over $10 \%$ again. Overall, China's economy has maintained a high growth rate for the past 10 years which is in sharp contrast to the period of stagnation before the economic reform.

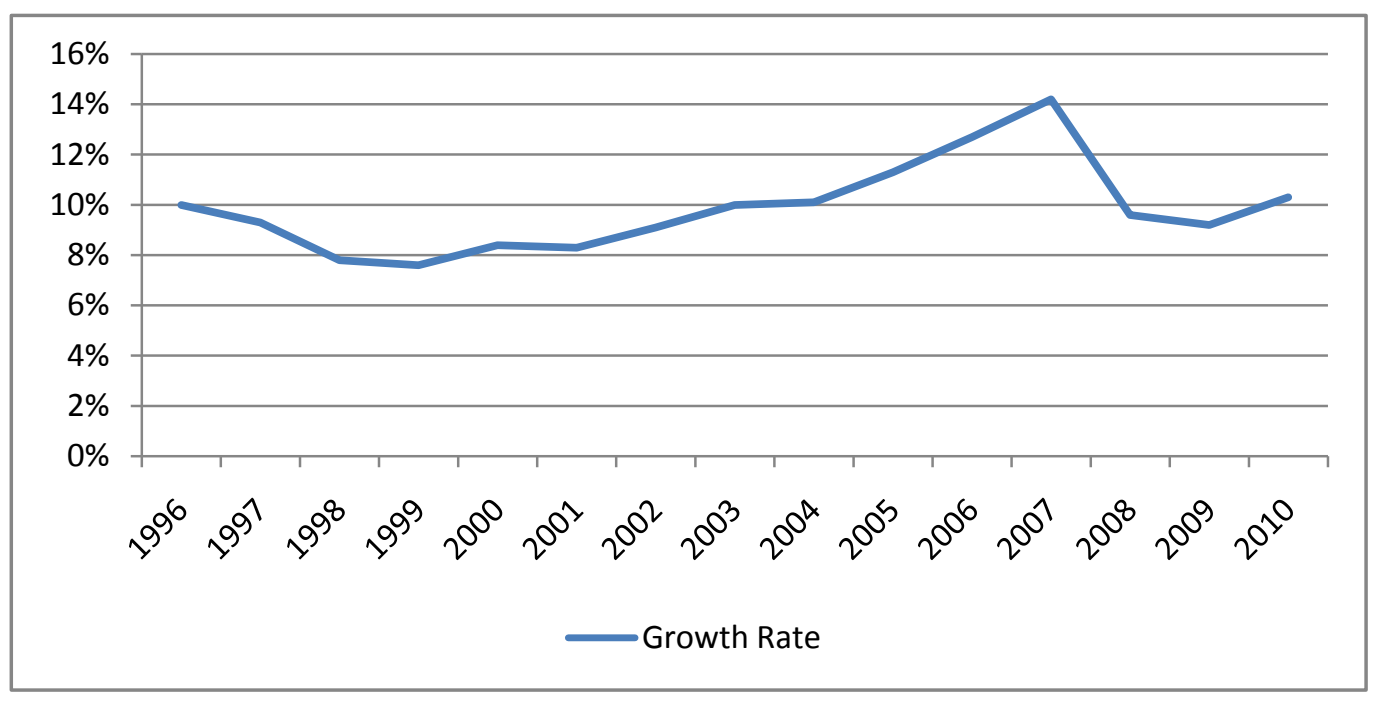

Figure 1: China's economic growth rate from 1996 to 2010

Source: World Bank 
A handful of studies conducted (e.g. Lin, Yao and Yueh, (2007); Song and Yao, (2007); Sally, (2007); Wu, (2008); among others) have suggested that China's economic growth in the recent years has been characterized by a combination of rapid increase in openness, change of the economy's structure and the foremost employment of the preferential economic policies. It seems that Chinese policy makers have gained experience from learning by doing and conducting various experiments in the paston the economic policy making. Hence, on the contrary to the industrialized economies, it has managed well to maintain a stable and sustainable rate of economic growth for the past ten years. Several scholars have paid attention to the issues of efficiency improvement in China (e.g. Liu, Hu and Khan (1997); Yi, Fan, and Li (2003); Peng (2005); among others). They found out the evident contribution of the total factor productivity on one hand. A significant variation among the regions' productivity growth, owing to the disparity in the level of development and the region's potential on the other hand.

For the purpose of comparison, we divide the Chinese provinces into four regions according to their geographical locations, economic structure and performance. The four areas are: municipal cities, eastern, middle and western regions. ${ }^{2}$ From Figure 2, we can see that the highest labor productivity occurred in the municipal cities, with an enormous productivity gap in comparison to other regions. This finding is very likely to be as a result of the preferential economic policies that these municipalities received and their important economic status in China all through history. Another reason for this high labor productivity difference is due to the smaller number of labor force compared to most of the other provinces. The eastern area has the highest labor productivity among the three geographical regions. Thanks to the earlier open door policies which were first implemented in the coastal cities and the provinces endowed them with higher growth rate. In contrast, the cities and provinces in the middle area and those in the western area have experienced sluggish growth, and the gap in the economic development levels hardly seem to diminish over time. Compared to other regions, western area has long been the least developed part as geographical location, and in terms of investment factors such as infrastructure facilities and human capital level. Although the government has carried out special "western development" programs, there seems to be no evidence or tendency towards the convergence in the development and productivity across the areas.

\footnotetext{
${ }^{2}$ Municipal include Beijing, Shanghai and Tianjin; Eastern region include Hebei, Liaoning, Jiangsu, Zhejiang, Fujian, Shandong, Guangdong, Guangxi, Hainan; Middle region include Shanxi, Inner Mongolia, Jilin, Helongjiang, Anhui, Jiangxi, Henan, Hubei, Hunan, and Western region include Chongqi, Sichuan, Guizhou, Xizang, Shaanxi, Gansu, Qinghai, Ningxia, Xinjiang.
} 


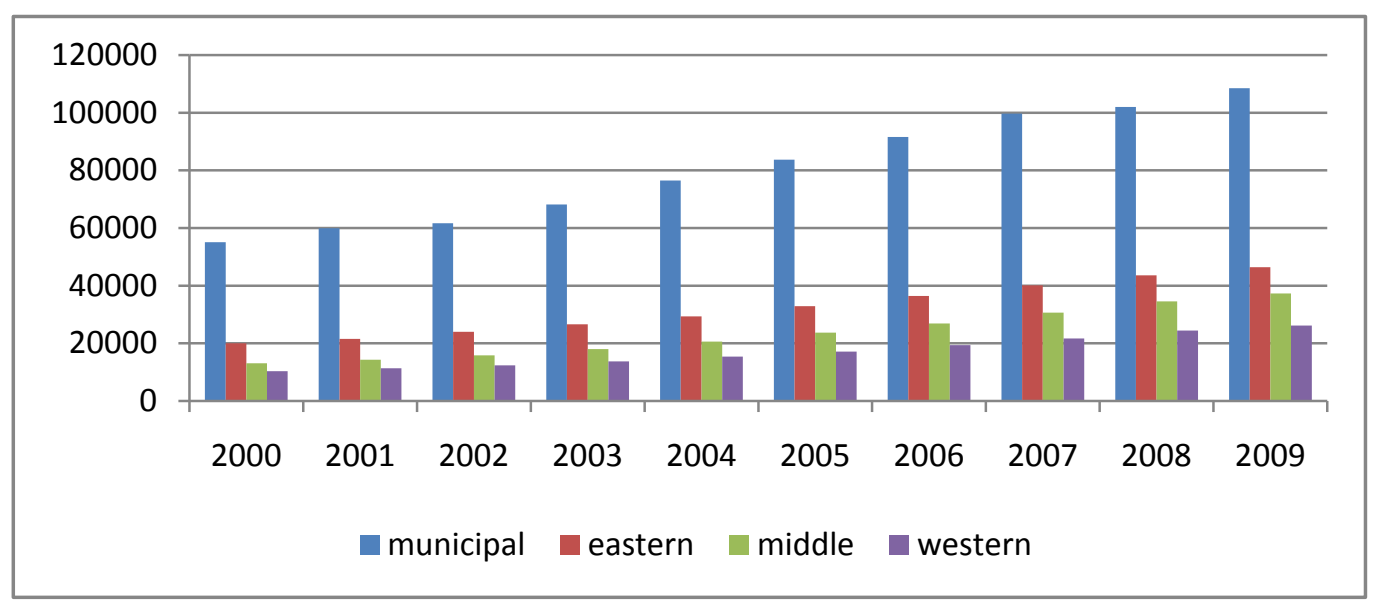

Figure 2: Labor productivity in China from 2000 to 2009 (Yuan/Labor) Source: National Bureau Yearbook 2000 to 2009

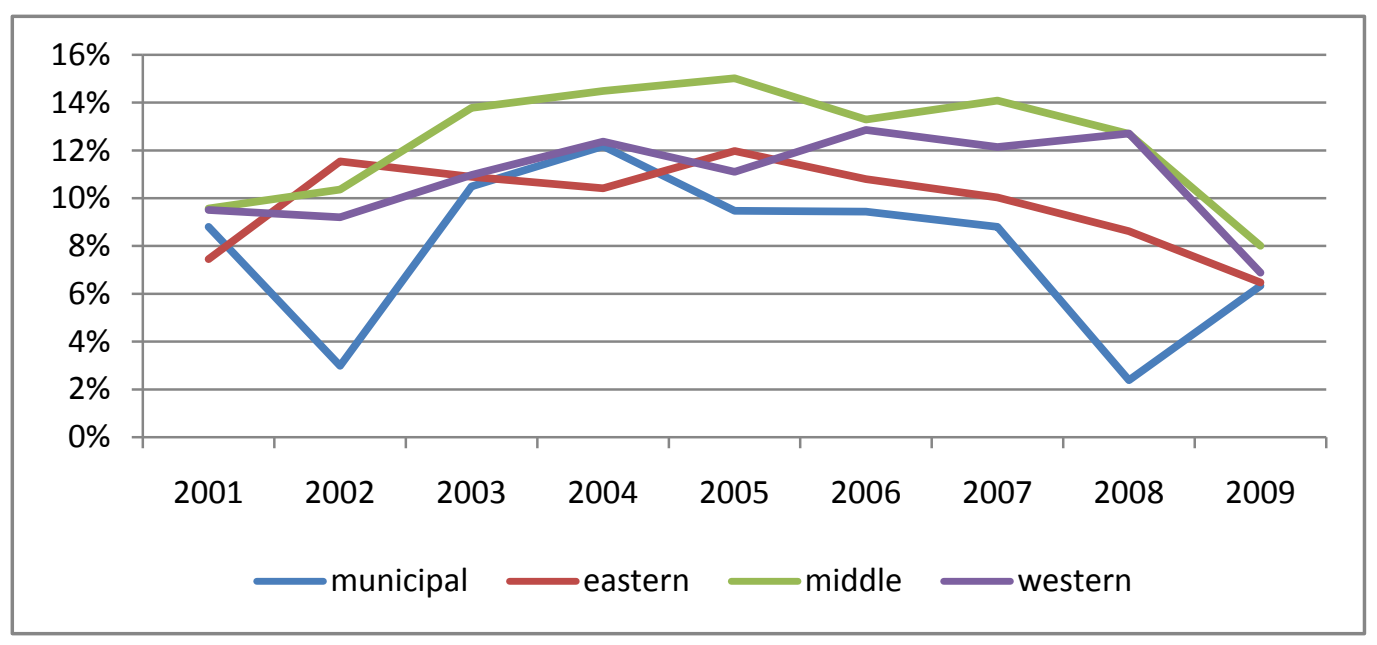

Figure 3: Growth rate of labor productivity from 2001 to 2009

Source: National Bureau Yearbook 2000 to 2009

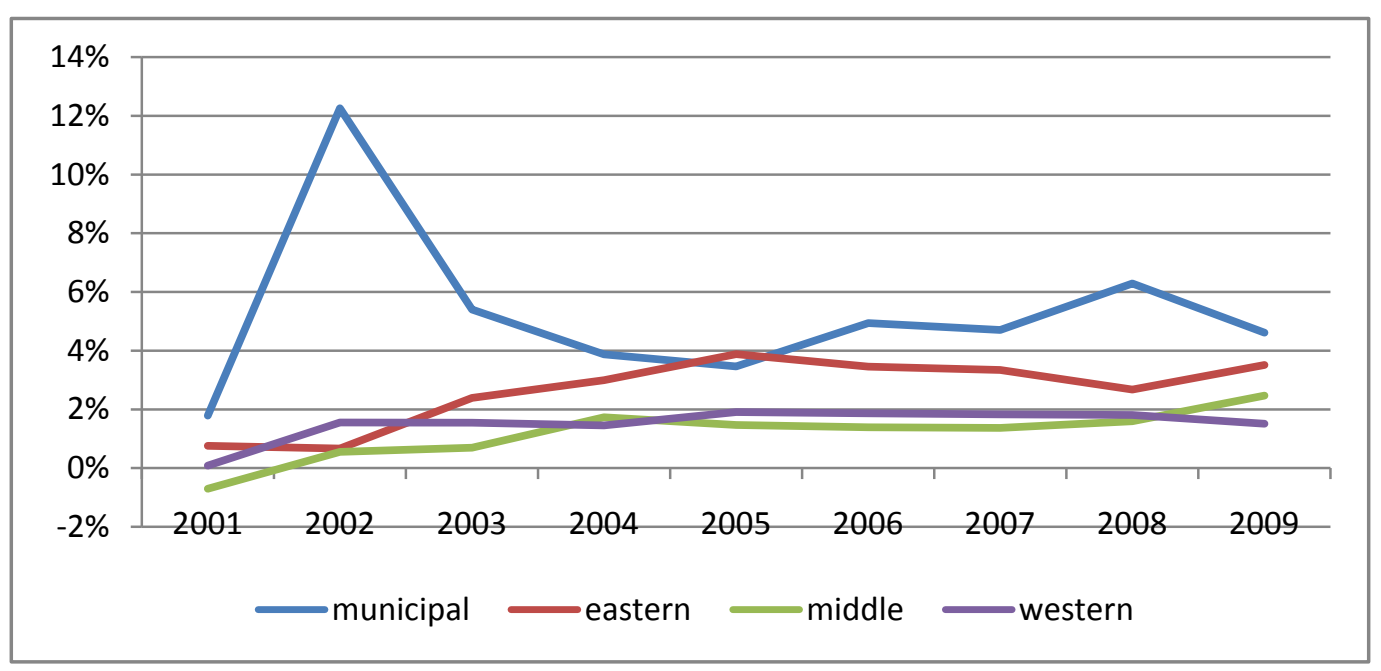

Figure 4: Growth of labor force from 2001 to 2009

Source: National Bureau Yearbook 2000 to 2009 
However, looking at the labor productivity in terms of level it does not give us the full story. As given in Figure 3, the growth rate of labor productivity varies among the regions in a given year. It is apparent that the municipal cities, featured with a higher level of labor productivity, but have the lowest growth rate in labor force among those four sample regions. In the year of 2002 and 2008, the labor productivity dropped sharply in relation to the number of labor and a shrink in the GDP which was affected by the IT bubble and global economy crisis. To explain the drop in 2002 we resolved to change the total labor force displayed in Figure 4. It is obvious that the growth of labor force in the municipal cities skyrocketed to $12.25 \%$ and this, results in a corresponding decline in labor productivity. While in 2008, an increase in the labor force was too small to address the large decline in the labor productivity. Thus, we consider more the side effects of the financial crisis which could affect the economy in those three cities through the decline in the Foreign Direct Investment inflows and exports. Therefore, their vulnerability to external shock is reflected in the declining labor productivity.

The middle region has the highest growth rate in labor productivity in comparison with the other regions, with a distinct $15.0 \%$ in 2005 . Then, it dropped to $12.7 \%$ in 2008 , and then, it ended around $8.0 \%$. From Figure 4 we observe that, there were no substantial changes in the total labor force for the same region and period. Therefore, we may conclude that the changes in the levels of GDP explain to a greater extent the fluctuation pattern of the growth rate and labor productivity variations.

Before 2006, labor productivity growth rate in the western and eastern regions have been close, but later the western area took the lead. Since, the growth of labor force was relatively small in both the regions, the GDP exerted greater effects on the labor productivity than that attributed to the change of the total labor force. As it was explained above, this is also consistent to the pattern we observed in the case of the middle region as well.

In summary, along with the rapid economic development, the level of labor productivity has kept rising, while the gaps between the regions showed no sign to shrink over time. On the other hand the growth of labor productivity has fluctuated over time. It is different among the sample regions. This is mainly due to their economic performance and structure. In the remaining part of this paperwe attempt to explain the temporal and regional variations in labor productivity and their possible key causal factors.

\section{Review of the Literature}

The literature on economic growth and the labor productivity in general and on the Chinese growth performance is increasing. Here, we briefly review on the labor productivity growth and its causal factors briefly.

In the recent years, the economic policy changes have certainly stimulated the flying dragon's massive appetite for growth. Along with the decay of the centrally controlled 
economy, a more market-oriented labor market has emerged with the urban private sector in China. It has distinguished itself with higher labor productivity. Cai et al. (2002) suggested that the early stages of the economic reform in China may be characterized as Pareto-improving ${ }^{3}$, so that almost all regions, where economies had been dominated by inefficient State-Owned Enterprises and collective agriculture, benefited from the change. In other words, the resources that the traditional planning economy could not efficiently allocate became available as a result of micro-management reform. This led to an increase in the labor productivity.

In another study, by using the multiregional input-output tables and disaggregated employment data, Ling and Lahr (2008) found that the potential causes for change in the labor productivity for the regions and the sectors in China comes mainly from two sources, that is the decreasing labor input per unit of gross output and from the changes in the value added share of the gross output. Several other factors also played a key role such as aggregate production mix, interregional trade, and final demand which also has an important but smaller effect on most of the regions' production and productivity and their sectors development in China.

Moreover, a handful of studies were focused on several particular factors which have significant influences on labor productivity or productivity. Below, we present these factors on which we are particularly interested in. These included investment in fixed assets, investment in education, the business volume of post and telecommunication, profit of enterprises, wages, share of industry, share of urban labor force and female labor participation rate. Each of these is described below in a detailed manner.

\section{Investment in Fixed Assets}

Fixed investment is a key factor for the production and regional development under both capitalist and socialist systems. The role of fixed capital is, especially evident in the socialist countries where the investment policy is a central feature to command economies (Konrai, 1992). Thus, an increase in the labor productivity is mainly a result of investment in the fixed capital and capital stock formation. Machinery, assembly lines, factories, infrastructure and technological innovation, with the latter are usually embodied in the new fixed assets.

It is noteworthy that the fixed investment in China is uneven among the eastern, central and western regions and among the cities. More developed and fast growing coastal provinces have recorded more rapid growth in fixed investment. They are less financed by the state budget and state banks, while the slowly growing provinces still rely greatly on the state contribution to finance their regional development programmes. As an evidence of capital investment impact on growth, Wei (2000) found out positive relationship between fixed investment and real GDP per capital in China. Demurger

\footnotetext{
${ }^{3}$ Pareto-improving suggests that given an initial allocation of goods among a set of individuals, a change to a different allocation which makes at least one individual better off without making any other individual worse off.
} 
(2001) also showed the empirical evidence on the links between the infrastructure investment and the real GDP per capita.

\section{Investment in Education}

The relationship between education and productivity in China has long been discussed. Numerous studies involve attributing economic growth to higher levels of human capital in the country. For example, it has been proved that the returns to education are higher in China than in the other transition economies, especially for those which used instrumental variable estimation method to cope up with the problem of endogeneity of schooling. Few examples of such studies include, Heckman and Li (2003), Chen and Hamori (2009), Fleisher and Wang (2005).

Chinese government has taken several important measures to develop the general education standard in response to the positive effects of education. As a result, since 1998 investment in education has increased proportionally more than the overall budget increase. Rural and urban students are exempted from the payment of tuition fees during their nine years of basic compulsory education since 2007/2008. The policy includes provision of free books and accommodation subsidies to impoverished students. Moreover, China is witnessing active cooperation and exchange in education with the rest of the world in particular with countries offering advanced education.

\section{Information and Communication Technology Capital}

Capital is in recent years divided into the physical plant and machinery capital and ICT capital components. A new economy or knowledge economy normally relies heavily on the use of communications and computer services. Some researchers have suggested that the effect of information and communication technology on the economic growth is significant and positive in the developed nations, but not in the developing countries. For the difference in impact is attributed to the nations' capacity in the utilization of the ICT capital. However, this has been a challenge for Heshmati and Yang (2006) who have showed that China has reaped the benefits of its ICT investment. Meng and Li (2002) provided some evidences on the China's ICT industrial development and diffusion as well.

It is reported that China ICT industry has been growing two to three times faster than it's GDP over the past 10 years. China's $11^{\text {th }}$ Five-Year Plan (2006-2010) featured the development of the information industry prominently. The Ministry of Industry and Information Technology has set the goals to move the industry up to a global value chain inorder to increase the productivity in manufacturing and service; continued focus on the government procurement and subsidies to pursue new technologies; foster the development of Chinese standards; and accelerate construction of IT networks, particularly in regard to rural broadcasting, telecommunications and telephone networks. In regard to the above mentioned support programs, the booming information industry is expected to maintain its robust positive and rapid growing trend in the coming years. 


\section{Profit of Enterprises}

The primary motive to study the effect of profit in enterprises has to do with the perception that if the current production is profitable enterprises would like to expand their production. Investment in machinery or technological capital, gives workers a partial stake in their company's performance. In a similar way, any other alternatives are likely to lead to an ultimate increase in the productivity. For example, Weitzman and Kruse (1996) argue that profit sharing system would be more effective in terms of improved labor productivity than wage system. As employees' gains are highly related to the outcome, so they would work harder to get higher pay. Morbey and Reithner (1990) find that the profit margin is strongly correlated with the $R \& D$ expenditure which intends to improve the future labor productivity.

\section{Wages}

Before the reforms, the Chinese government had strong distributional objectives, which was pursued mainly by directly controlling over the state enterprise wage rates and general hiring decisions. During the reform period, similar controls over state enterprises continued, but use of them had to reflect competition with the new non-state sector which was generally free from these controls (Gordon and Li, 1997). When China's labor market became more competitive, the level of labor's real wages is more associated with their marginal products. Alternative views of wages also emphasize the role of firm-specific human capital and the effect of different incentive provision on the wages. This may have stimulated the productivity of workers.

\section{Share of industry}

The share of industry in the economy is an important factor for its competitiveness, openness, productivity and overall capability of nations. Kuznets (1979) stated that "it is impossible to attain high rates of growth of per capita or per worker product without commensurate substantial shift in the shares of various sectors". The hypothesis that structure change is an important source of growth and productivity improvement is a central tenet of the growth accounting literature (Maddison, 1987).

China as an emerging economy has gradually transited from an agriculture-based to an industrial-intensive economy. It relies increasingly on the manufacturing sector. The service sector is also developing in parallel to the manufacturing sector and this indicates growth in the domestic market and a support in the industrial sector. This underscored the fact that the Chinese economic miracle has entailed changes in the distribution of inputs and outputs across the sectors as more capital intensive activities have normally higher level of labor productivity.

Recently, many economists are wondering whether the second (manufacturing) industry could support the rapid growth in China sustainably, not only due to the shrinking of demand in the international market, but also because of the cost of production is increasing, especially the labor cost. Moreover, most of the share of the tertiary sector in the past five to six years appears to grow faster in the tertiary sector 
than in the other sectors. This was concentrated in the coastal provinces like Fujian, Guangdong, Shandong, Zhejiang. If China follows the typical pattern of the Asian tigers, it will soon start to expand its service industry to eventually dwarf of its current dominant manufacturing sector. This path of development has been observed in the case of the developed countries where expanding service sector replaces the shrinking industry sector.

\section{Share of Urban Labor Force}

Although China set several barriers to restrict rural to urban migration, owing to a well acknowledged surplus of labor in agriculture, millions of rural laborers have joined in the migration flow inorder to find better opportunities in the major cities. Au and Henderson (2004) empirically showed that migration restrictions across the cities, as well as rural-urban migration restrictions, have left many cities significantly undersized with unexploited economies of scale, resulting in large productivity losses. Still, in 2008there were around 140 million rural migrants in China, which is probably the largest domestic migration flow in the human history (Cai, 2008). According to the statistics of the National Bureau Yearbook, over 60 percent were classified as rural labor by 2010, compared to 70 percent a decade ago.

The rural-urban migrants have become the main source of labor force in the Chinese manufacturing sector. Yet, most of them possess low level of education and skill. The increase in the migrant's population affects the labor productivity to a greater extent. Thus, another main challenge facing the labor market is to improve the productivity. This seems to be about how to absorb such large number of surplus labor into quality jobs. This massive transformation requires enormous investment in education, housing, transportation health, and other infrastructures. Improved education and skills of labor enhances its productivity.

\section{Female Participation}

For the last ten years, the average female labor share is maintained by an approximate $37 \%$. One of the reasons is that the share of female employment is lower than that the male counterpart. Another probable reason could be related to the employment discrimination, that is, the manufacturing sector employers tend to have a consideration on female physical condition and potential interruption in form of absenteeism for having children. Nevertheless, an increase in female working participation can be observed in some areas such as textiles, electronics manufacturing and also in the service industry in China. No study has particularly discussed on how female participation affects the labor productivity in China, so we go deeper to explore the reason behind this. 


\section{Data}

For the empirical part of this paper, we compiled published data obtained from both the China Statistical Yearbook and Labor Statistical Yearbook for the period of 2000-2009. Despite, the time span being short it provides updated information on the development of labor productivity in China. As the monetary variables are initially expressed in nominal prices, they are converted to fixed prices by using the consumer price index obtained from the United Nations (2000 is the base year).

The raw data set comprises a number of variables. These include the following variables for 31 provinces for the recent 10 years: Business volume of post and telecommunication services (POS), Expenditure in education (EDU), Gross domestic product (GDP), Investment in fixed asset (INV), Total industry value (IND), Profit of industrial enterprises (PRO)(all in 100 million Yuan); average annual wage (in Yuan); Total labor (LAB), Urban labor employment in urban units, Female employment in urban units (all in 10000 persons).

We transform the raw data and define several new variables for the estimation part. This includes Labor productivity (LABPRO), Capital intensity (INVLAB), Education expenditure per labor (EDULAB), Post and telecommunication services per labor (POSLAB); Profit for industrial enterprises per employee (PROLAB); Share of industry (SIND), Share of urban labor (SURB), and Female labor participation (SFEM) in the labor market. Growth of all the variables except for those expressed in shares has been calculated respectively.

Specifically, we use the adjusted GDP, as after the first Economic Census in 2004. It was evidenced that the regular annual accounting exercise had overlooked the most slippery parts of the economy: the services sector. As for female's participation in the labor market, we use share of female employment in urban units as a proxy. This is due to the unavailability of statistics that captures the female employment in non-units workplace, which are urban private enterprises and individuals. A clear disadvantage is that one cannot generalize an accurate female participation from the urban units to the entire labor market. Nevertheless, the female share of urban units in the labor market is an average of around $70 \%$. Therefore, the results obtained can be suggestive on the role of female participation. Moreover, we use business volume of post and telecommunication service as a proxy to Information and Communication Technology. This is also due to the lack of direct statistical information.

In addition, the dummy variables are included to capture unobservable time-invariant regional effects (such as skills, planning and management differences at the provinces and location advantages/disadvantages) and region-invariant (such as central or local economic policy effects, economic shocks). The total number of observations is $10 * 31=310$. Table 1 shows the specific definition and summary statistics of the used data in current study. 


\section{Model and its Estimation}

In the recent economic development literatures, panel data analysis has become popular in estimating the growth in productivity across regions and countries (see e.g. Islam, 1995; Griffith, Redding and Reenen, 2004; and Heshmati and Shiu, 2006). The main reason lies in its ability to allow for differences or heterogeneity in the aggregate production function across economies, which is significantly different from those obtained from single cross-country regression. In the panel data econometrics, in addition to those unobservable individual factors absorbed by the independent variables, the error term $\varepsilon_{i t} c a n$ be decomposed into $\varepsilon_{i t}=v_{i}+\lambda_{t}+u_{i t}$, where $v_{i}$ denotes unobserved region-specific effects, $\lambda_{t}$ denotes unobserved time-specific effects and $\mathrm{u}_{\mathrm{it}} \mathrm{is}$ the random error component with distribution $\mathrm{N}\left(0, \sigma^{2}\right)$. Nevertheless, conventional cross-country methods have no time-specific effects for a given time period and neglect the error terms of $v_{\mathrm{i}}$. Empirical evidence shows that this bias results due to the neglecting of the two effects which possibly impacts the magnitude of parameter estimates. This is not negligible.

Since, we collect all the comparable regions in China in our sample, it is reasonable to apply a fixed-effects panel data multiple regression function methodology. That is to say, we assume the effects of the remaining unobserved region-specific and the time-invariant effects for a given region are fixed. With the above given reason, these effects can be absorbed into the intercept term of a regression model and are assumed corrected with other independent variables. Thus we use regional dummy variable $\left(\mathrm{D}_{\mathrm{i}}\right)$ and time dummy variable $\left(T_{t}\right)$ to capture unobservable regional-specific $\left(v_{i}\right)$ and time-specific $\left(\lambda_{t}\right)$ effects.

Another econometrics concern is the issue of heteroskedasticity. This is against the assumption of the constant variance within the model. For many panel studies involving cross-sectional units of varying sizes have found variance of errors across the individuals $\left(\sigma_{\mathrm{vi}}{ }^{2}\right)$ and the variance of random error term $\left(\sigma_{\mathrm{ui}}{ }^{2}\right)$ could be either or both varied across individual units (see e.g. Baltagi and Griffin, 1983). Though heteroskedasticity does not cause bias or inconsistency of estimators, the standard errors are biased directly on these variances. Therefore, they are no longer valid for constructing the confidence intervals and t statistics. To avoid that kind of problem, heteroskedasticity-robust procedures have been frequently applied.

We proceed in a stepwise manner to analyze the development and the sources for labor productivity. First step is to examine the contribution of labor to the gross domestic productivity among other production factors. In doing so we estimate a production function model where the specification in logarithmic form is as follows: 
(1)

$$
\begin{gathered}
\ln Y_{i t}=\beta_{\mathrm{o}}+\beta_{1} \operatorname{lnLAB} \mathrm{B}_{\mathrm{it}}+\beta_{2} \operatorname{lnINV}_{\mathrm{it}}+\beta_{3} \operatorname{lnEDU} \mathrm{it}_{\mathrm{it}}+\beta_{4} \operatorname{lnPOS}_{\mathrm{it}}+\beta_{5} \mathrm{SIND}_{\mathrm{it}}+\beta_{6} \mathrm{SURB}_{\mathrm{it}}+\beta_{5} \mathrm{SFEM}_{\mathrm{it}} \\
+\sum_{\mathrm{i}=2}^{31} \mathrm{D}_{\mathrm{i}}+\sum_{\mathrm{t}=2}^{10} \mathrm{~T}_{\mathrm{t}}+\mathrm{u}_{\mathrm{it}}
\end{gathered}
$$

where, $\ln Y_{\mathrm{it}}$ is the is the logarithm of total GDP of province $\mathrm{i}(\mathrm{i}=1,2, \ldots, \mathrm{N})$ in period $\mathrm{t}$ $(1,2, \ldots, \mathrm{T})$. Four of the determinants variables labor (LAB), investment (INV), education (EDU), and Business volume of post and telecommunication services (POS) are in the logarithmic form; while three of the determinant variables industry share of the economy (SIND), urban share of population (SURB) and female share of labor force (SFEM) are expressed in the form ofshares; $\mathrm{D}$ and $\mathrm{T}$ are vectors of unobservable fixed region-specific and time-specific effects. $\beta$ is a vector of unknown parameters which are to be estimated and $\mathrm{u}_{\mathrm{it}} \mathrm{is}$ a random error term following the tradition. It is assumed to have zero mean and constant variance.

The objective of this paper is to analyze the development and the sources of labor productivity. After having established the relationship between GDP and labor, we compute labor productivity and investigate its determinants. We assume that the labor productivity is affected by similar variables as those of the production function written as:

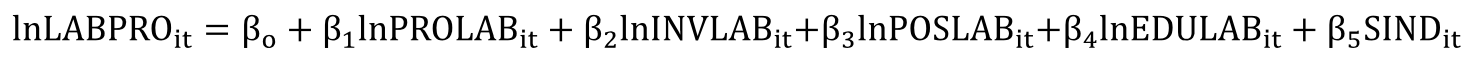

$$
\begin{aligned}
& +\beta_{6} \text { SURB }_{i t}+\beta_{7} \text { SFEM }_{i t}+\sum_{i=2}^{31} D_{i}+\sum_{t=2}^{10} T_{t}+\varepsilon_{i t}
\end{aligned}
$$

where, the dependent variable is the logarithmic form of labor productivity which is defined as the GDP per capita labor. To explain these relationships more clearly, we divide the INV, POS and EDU with the total labor population (LAB) to express these variables per unit of labor. Since, the labor population varies from one region to another; changes in the total amount of the determinants in one region cannot reflect their relative changes per labor. For instance, a large increase in the investment in education of one region may turn out to be relatively small per labor when the labor population in that area is large. Capital intensity (INVLAB), Post and telecommunication intensity (POSLAB) and human capital (EDULAB) are expected to positively affect the labor productivity.

Additionally, we intend to find how the average wage and profit of the industrial enterprise per employee can affect the labor productivity. To achieve this objective, we add logarithmic wage and profit per employee on the right side of the function. As higher wage reflects higher skill and a high profit results in the potential investment for expansion, both these coefficients should positively affect the labor productivity. 
Other than study labor productivity in level we are interested in examining its growth rate as well. To see how the labor productivity develops along with time we use the following equation:

(3)

$$
\begin{aligned}
\text { GLABPRO }_{\text {it }}=\beta_{\mathrm{o}} & +\beta_{1} \text { GPROLAB }_{i t}+\beta_{2} \text { GINVLAB }_{i t}+\beta_{3} \text { GEDULAB }_{i t}+\beta_{4} \text { GPOSLAB }_{i t}+\beta_{5} \text { SIND }_{i t} \\
& +\beta_{6} \text { SURB }_{i t}+\beta_{7} \text { SFEM }_{i t}+\sum_{i=2}^{31} D_{i}+\sum_{t=2}^{10} T_{t}+\varepsilon_{i t}
\end{aligned}
$$

Where, the growth of labor productivity is explained by the same explanatory variables measured per unit of labor but using their growth rates (GPROLAB, GINVLAB, GEDULAB and GPOSLAB). Also the share of IND, SURB and FEM are entering the relation as conditional variables, $\mathrm{D}$ and $\mathrm{T}$ are also used to represent the specific effects attributed to the regions and their time periods.

\section{Empirical Results}

In this section, we provide empirical evidence from China on both levels and the growth rate of labor productivity. First, we demonstrate the important role that labor force has played in the GDP and its development. Second, we sort out the sources that significantly affect the level of labor productivity. Finally, we look at the growth of labor productivity and concluding that labor productivity has an increasing trend in the last decade and it varies across provinces and regions. Thus, in total we estimate three models: a production model, a labor productivity model in level form and another in the growth rate form. All these models have been estimated using the Least Square Dummies Variables (LSDV) method. Further to maintain the efficiency of the coefficients, each equation has been adjusted using heteroskedasticity-robust procedures. The coefficients and the adjusted standard errors for these three models are represented in Table 2.

\subsection{Production Function Model}

The production model aims to estimate the output-input relationship accounting for the production characteristics. From the first column, the adjusted R-square of the production function is 0.9986 indicating our data fits the model well. Labor and fixed asset investment, are significant at $1 \%$ level with positive signs. It shows that both the labor accumulation and capital increment have significant contribution towards the economic growth. This is consistent with the neoclassical economic growth theory. The main objective is to see how the labor affects the GDP among other production factors. According to the results, a $1 \%$ increase in the labor leads to $0.23 \%$ increase in GDP. The labor elasticity is larger than the output responsiveness to a $1 \%$ change in the 
capital stock, which is only $0.17 \%$. The sum of labor and capital stock elasticity is about 0.40 suggesting decreasing returns to scale.

It is widely accepted that the manufacturing sector has fueled the growth of the Chinese economy. In order to test such hypothesis and impact we estimated the effect of the industrial share of the GDP. In our model, the largest contribution comes from the share of the industry, suggesting $1 \%$ increase in the share of manufacturing $0.52 \%$ increase in the GDP. This is the evidence of the fact that manufacture has been the backbone of China's economy and it is the reason for China's rapid development.

Special concerns have been taken on the effects of technological change, migration, education, and female worker participation on the level of GDP. Significant and positive coefficient proves that a rise in the business volume of post and telecommunication will stimulate the GDP. And consistent to the fact that widespread use of telecommunication, computer, and the Internet in China affects the economy on all fronts. It is reported that the Chinese telecommunication sector's growth rate was about 20\% in the early 2000's, and by June 2010, China had 306 million fixed-line subscribers and 796 million mobile customers, totaling to 1.1 billion telephone users. The development in the ICT area helps in the growth of economy by bringing a much more efficient and convenient wage of communication, improving production methods, and changing consumer behavior, etc.

Another change that has been undergoing for about three decades is China's transformation from an agricultural society to a modern society that is dominated by industry and service sectors. It gives birth to the labor force migration reflected by an increase in the share of urban labor. This phenomenon has positive and significant effects on the GDP underlying that industry. Modern services are capital intensive sectors which enjoy a higher productivity. Therefore, these sectors generate a higher value of output for the same inputs compared with the less developed and labor intensive agricultural sector.

Unexpectedly, the estimated effect of education is weak and negative; indicating that if we invest more in education it is likely to lead to a negative effect on the GDP. An explanation for this result is that Chinese government, in terms of education invests more in the less developed areas than in the developed areas. The aim is to help the less developed regions to catch up with the developed provinces. Another explanation is that we have used the total expenditure for a province without consideration of its population. Thus larger province may get larger expenditure regardless of the economic situation. If a large number of provinces that are relatively less developed receive more education investment because of their larger population, we can arrive at a negative sign on education. Investment in education does not need to be transmitted into a higher manufacturing GDP but to be absorbed into the administration and service with low productivity with long lag adjustments.

As for the female variable, the coefficient is not statistically significant, suggesting no clear answer as to whether an increase in the female labor force participation in the 
labor market affects substantially the GDP. In case of high wage gap but equally productive labor, an increase in female labor force participation would positively affect the GDP. However, in the absence of the wage gap and low productivity of females or their flow into the low productive service sector with an increased participation would reduce proportionally the GDP of the provinces.

Time represents the state of technology or the rate of the technological change. The coefficients for time dummies are all significant at the $1 \%$ level. As time goes by, the scale gets larger suggesting technological progress at an increasing rate. This corresponds well with the China's economic expansion that we have discussed before. For the purpose of comparison, interpretation of the regional dummy is also presented in the light of the regional economies and heterogeneity in productivity performance. We find that the eastern region and the three large cities have performed better than the central and western areas, with the latter being the worst performer. Beijing serves as the base or the reference province. Other than Shanghai, Jiangsu, Shandong, and Guangdong, the sign of the remaining provinces are negative, interpreted as having smaller GDP than Beijing. Among all the provinces, Xizang, Ningxia, and Qinghai, all in the western region, are the least developed provinces in China.

\subsection{Labor Productivity Model}

The model 2 differs from model 1 by the latter, instead of using the GDP directly as the dependent variable, the GDP variable is divided with the total labor force. This newly defined the variable that represents the output per unit of labor, in other words, the labor productivity. The explanatory variables are also expressed as per unit of labor. Therefore, instead of production model the model is labeled as a labor productivity model. The R-square for labor productivity level model is 0.9955, and most of the coefficients are statistically significant at the $1 \%$ level.

From the third column of Table 2, the investment in capital intensity exerts a positive and significant influence on the labor productivity. This shows that when a labor has more capital to employ, he or she will have higher productivity. This is consistent with the empirical evidence from the developing economies and in particular with the capital intensive production structure in more productive manufacturing industry sector as well as in the less productive agriculture.

On the other hand, the share of industry in the total GDP at the province level exerts the largest influence on the labor productivity. Among all the factors that we are concerned with this can be the most important source of the labor productivity. The expansion of industry is a key factor that along with other improvement has eventually affected the labor productivity in China. This is consistent with the empirical findings in the literature. Chen and Feng (2000) conclude that the trend of industrialization in China is consistent with the progress of technological innovation and upgrading. This allows the labor productivity to improve. Besides, structural changes within the industry also 
matters in this regard. The empirical work of Hoffmann (1958) offers the perception that industrial development is a general shift with relative importance from light to heavy industries where the former has relatively low ratio of capital to labor, while the heavy industries have relatively high ratios. As more capital-intensive activities normally have higher levels of labor productivity, this shift from light to heavy industries will generate extra labor productivity growth at the aggregate level.

As for the share of urban labor, it also gives positive effects on labor productivity. Migrants from the rural areas contribute to the increase in the urban labor stock by giving up agricultural work and they seek non-agricultural work in the urban area primarily in manufacturing and construction areas. The positive effect suggests that urban employment still absorbs high productive labor. Lack of strict and costly labor market regulations combined with increased capital intensity might be the two other factors that explain continuous high provincial labor productivity. However, from a comparative perspective, it is clear that the degree of urbanization in China remains low. Due to the system of social exclusion in employment, everyday life and social communication, most of the migrant workers cannot settle in the cities. This implies that a great number of surplus labors still remain in the rural area. This affects the economic and non-economic (dis)advantages of migration of labor.

Two other variables, the enterprises' profit per employee and the average wage for labor in each region has a positive turn out as expected. Apparently, annual wage per employee is much more influential than the average enterprises' profit per employee. The former induces $0.20 \%$ whereas the latter has $0.03 \%$ increase in the labor productivity. This is in response to the $1 \%$ increase in the respective variable. This can be understood, as wage is highly and directly related to the individuals' welfare and performance. For employees, would like to increase their productivity to gain a higher wage and promotion. On the other hand, profits of enterprises are mostly enjoyed by owners. This might be used to enlarge the business by investing in additional physical, technical or human capital. Though by doing this the output would increase, and will result in an increase in the labor productivity, the effect from profit is smaller than that of the wages.

Development in the post and telecommunication sector investment helps the labor productivity to grow. This is consistent with the finding from Wu (2008) and Heshmati and Yang (2006) concerning the effects of ICT investment on productivity in the case of China. This is in contrast to the Kraemer and Dedrick's (1999) findings for Asian countries. This suggests that in general, ICT investment was negatively correlated with labor productivity, as these countries rely more heavily on manufacturing rather than on the service sectors. Therefore they are more likely to reap gains in productivity from investment in non-ICT capital. The positive effects in China may be caused by a drop in the price of the ICT equipment, break up of monopoly since 1993 and bureaucratic reform during the late 1990s, and the development of the service industry.

In this model, the female participation is not as significant as well. Therefore, it has no 
special influence on the labor productivity level. This may be attributed to the fact that there is little change in the female participation in those years and their performances are not different from their male counterparts. Investment in education per labor is positive, however, it is also insignificant, which is unexpected and hard to explain. Investment in education is expected to impact the productivity positively. However, it takes time to capture effects of such investment. Some education effects are associated with acquisition of skill from abroad and receipt of foreign direct investment and its spillover management and skill effects which are not captured through Chinese investment education.

The time dummies are insignificant at a 5\% level. It is interpreted that for 10 years no substantial change is observed in the labor productivity. This can be controversial. We find that the problem is caused due to high correlation between wage and time trend. An exclusion of wage from the model results in time dummies. They are all significant and they positively affect the labor productivity. Nevertheless, in order to be theoretically consistent in the model specification we keep wage in this model and investigate the relationship between time and labor productivity in our next model.

Provincial dummy variables are all significant at $1 \%$ or $5 \%$ levels. As expected, the three municipal cities have the highest labor productivity with Shanghai being the highest and Tianjin the second. This is consistent with the government statistics. The high labor productivity is accounted to be publicly guided preferential investment policy, with high inflows of FDI and optimal geographic location for these three cities. Labor productivity in other provinces is much lower. Guizhou, which is the poorest province in China, has the lowest labor productivity. These three provinces has $27.1 \%$, $42.2 \%$ and $70.0 \%$ lower labor productivity than the reference city of Beijing, respectively, implying large disparity in labor productivity at the provincial level in China.

\subsection{Labor Productivity Growth Model}

Finally, we investigate the growth of labor productivity by specification and estimation of model 3 where the dependent variable is measured as growth in labor productivity. R-square is 0.7376 and most of the coefficients are statistically significant at $1 \%$ and $5 \%$ levels. The explanatory variables expressed in terms of levels have been changed into growth rates while the shares remain the same.

From the fifth column of Table 2, we can see that industry share again proves to remain the largest contributor to the growth of the labor productivity. This emphasizes its influence on China's economy. Growth in wage exerts the second largest effect followed by the growth in post and telecommunication investment. Growth in profit in enterprise also displays a positive influence, though the scale is somewhat small. Growth in the share of female on the total labor force remained insignificant in our third growth rate model. 
There are two obvious changes in the estimated coefficients in Model 3 compared with those of Model 2. The first one is that the effect of share of urban labor becomes negative in the growth rate model. Accompanied by the conclusion in the function (2) an increase in the share of urban labor can lead to an increase in the level of labor productivity. We draw the conclusion that increase in urban labor has a decreasing return to the economies of scale. Although the expansion of urban labor force can improve the level of labor productivity, its positive effect becomes smaller and smaller. One explanation to this phenomenon could be that most migrants receive less education and training. Thus the growth of labor productivity has been limited. The second change comes from education. It becomes significant and affects positively the growth of the labor productivity. This may be because the less developed areas are more likely to be affected by the growing investment in education. Therefore, they have a larger growth in the labor productivity. For example Xizang has 79.1\% lower labor productivity than Beijing which has a higher growth rate than many other provinces like Jiangsu, Shandong, etc. These provinces enjoy a higher labor productivity.

The time dummy variables are all significant and positive except for 2009, an average $6.0 \%$ growth rate proves that China has an increasing trend in labor productivity growth, and growth rate in Tianjin. Shanghai is also not significantly different from zero. Apart from these three municipal cities, the middle region has the highest growth rate than the eastern and western regions. Whereas the differences between the regions are small meaning that the labor productivity is growing at the same rate. If the growth rate maintains the same, then the convergence in the labor productivity will be difficult to achieve in the future.

Initially we intended to include GDP and the growth of GDP as the explanatory variable in Model 2 and 3. These are aimed to serve as a proxy of the size of the provincial economy which can impact labor productivity largely. However, due to the correlation effect with other variables and subsequent confounded effects, these two variables are found to cause serious troubles for the estimation and interpretation of the result. Thus, we drop them from the model specification to keep our model consistent with reality.

\subsection{Policy Implications of the Result}

Ever since economic reform and openness set its foot in China around 30 years ago, Chinese people welcomed a new era of economic growth, one that is marked by market-orientation, industrialization, and urbanization. Government funding for R\&D and education gave birth to numerous high-tech parks in China. During this process, hundreds and thousands of factories have been built in the southeast coastal areas leading to a boom in productivity. It helps China to stay competitive in the world market. The regions in the western part are trying to catch up with the other regions by better utilization of the improved infrastructure and taking advantage of the faster growth attributed to their backwardness position (lower initial level of development). 
While China is on the right track heading to a larger economy, there can be too much of a good thing. That is, the brisk expanding does cause regional disparities across the inner land which may lead to social, political and economic instability and unrest. Our results have also reflected on this fact that, the municipal cities not only have much higher labor productivity than other regions but also enjoy a higher growth rate. Gaps between the other three regions are obvious. They are not shrinking over time. The increasing gap suggests divergence in the regional labor productivity.

So what is the core that is underneath China's economy and how to narrow the gap within it? Without doubt, labor productivity is one of the primary concerns for China. This is the most populous country around the world and it enjoys a large share of labor force. According to our results, the share of industry, share of urban labor, average wage per employee, capital intensity and the ICT largely affects labor productivity. Therefore, aiming to maintain a high level of growth and competitiveness, we provide several policy suggestions as below.

In the light of our analysis, the output from industry with respect to GDP, the capital intensity and ICT investment are contributing positively to the labor productivity. We are concerned on ways to expand the industry output and where to invest the capital and ICT. The government is encouraged to invest more in the capital stock especially in the heavy industry sectors such as, energy, iron, steel, machinery and chemical etc. In these sectors a higher economic returns is expected than the returns to the investment in the light sector. It is worthy to note that, most of coalfields are located in the central regions. Thus a special and favorable economic policy is required to support the coal sector in those areas and to narrow their gap to the developed regions.

Nowadays, most of the manufacturing plants are located along the southeast coastal line, where comprehensive public investment programs in $R \& D$ and ICT are recommended. This is because these areas have accumulated certain level of experience with information technologies. Therefore, they are capable of absorbing new technological innovations and ICT investments to result in better returns to production. However, for the western regions, a rapid technological development is probably inappropriate. This is due to their insufficient public infrastructure, low concentration of skilled labor and inconvenient transportation system. Thus the government may consider introducing the matured technology from the east to the west and eventually improve the manufacturing standard in the western areas as a whole.

Urbanization, featured by the development of the service sector and construction, shows its potential in raising labor productivity. As a common trend of development, surplus labor force from the rural area would flood into all walks of life in the urban areas. It is important to absorb and allocate the excess rural labor force properly in terms of their education, skill and other characteristics to prevent wage inequality, increased crime in urban areas and other negative social issues. Since rural migrants usually receive lower education than urban residents, professional education and job training programs may be offered targeting rural residents to improve their productivity 
and matching their skill requirements. An increased number of institutions and organizations involved in helping the rural people to find job will minimize their time and monetary cost of migration. Last but not the least, concerning the implementation of low-rent housing policies very little has been done by the state to accommodate the migrants in the cities.

Wage level is highly associated with labor productivity. In practice, so far the average wage is determined by the market and enterprises in different regions. In order to make wage a tool for promoting labor productivity, government should encourage enterprises in the western and central regions to offer a higher wage. This can be facilitated by the state provision of some subsidies and preferential policies. Besides, government could attract more educated and high-skilled workers to disadvantage regions to speed up the development. This can be done by the introduction of different incentives/reward systems.

\section{Summary and Conclusion}

Labor productivity is a multifaceted issue that is essential for the general economic performance and other issues in the labor market such as labor demand and employment. This paper empirically investigates the production relationship, sources and the developments of labor productivity in China based on China's provincial data. Specifically, panel data model with fixed effects are applied on the provincial level data for the period 2000 to 2009.

We identify several determinants of the labor productivity and find out the share of industry output, investment in fixed asset, total volume of the business post and telecommunication investment, profit of enterprises, and the average wage for labor, have positive effects on the labor productivity both in level and in growth rate. As for investment in education, positive and significant effects have been observed only in the growth rate model formulation. On the other side, the share of urban labor has an ambiguous effect. It is helpful to improve the labor productivity, but it may also bring negative effects on the growth of the labor productivity. Among the explanatory variables, the share of female workers displays no effect on either labor productivity or on the total GDP. Considering labor productivity it suggests no heterogeneity in gender.

We use dummy variables to capture both time representing technology and regional heterogeneity effects. All our results show an increase in the labor productivity and its growth along with the time trend. There are severe regional disparities in labor productivity and its growth rate over time. There is no sign of convergence in the labor productivity across the Chinese provinces. However we can narrow the gap between the poorer and richer provinces by the reallocation of investments and by focusing on the more influential factors. To be more specific, there are several policy implications which can be extracted from our findings about labor productivity and its determinants.

Share of industry exerts a large and significant impact on the GDP production and labor 
productivity suggesting a positive association with the economic growth. To develop the economy as a whole, improving the productivity in industry, promoting international trade to stimulate industry output, are recommended. Instead of investing in the eastern area, the middle and the western areas are preferred in order to narrow the economic gap. This is done at the expense of using resources more effectively.

Urbanization can improve the labor productivity to some extent. As a large amount of labor migrate from the countryside to the urban area, the government should consequently consider training and other consulting services to enhance labor productivity. It should also enable more productive allocation of labor resources to regions with low development to enhance regional equality in development.

Our results also suggest that employers can increase productivity by paying higher wages. Government may encourage enterprise to use wage as one of the tools to promote workers' productivity. It is worth to note that this suggestion certainly increases the production costs and the extent to which doing so affects profits or economic efficiency would be an interesting topic for future research. However, higher labor productivity will enhance the competitiveness of the Chinese products at the national and international markets.

The regional dummy variables display that the disparity is still an urgent problem that needs to be tackled in China. The growth rate in labor productivity is nearly the same. This is bad for the less developed areas to catch up with the developed areas. Thus, in order to narrow the gap of the labor productivity and development, allocation of investment resources or design of economic policies should give priority to the middle and western regions. 


\section{References}

Au, C.C. and Henderson, J.V. (2006).How Migration Restrictions Limit Agglomeration and Productivity in China,Journal of Development Economics 80, 350-288.

Baltagi, B.H. (2008).Econometric Analysis of Panel Data.John Wiley \& Sons, Ltd, U.S.

Baltagi, B.H. and Griffin, J.M. (1983). Gasoline Demand in the OECD: An Application of Pooling and Testing Procedures, European Economic Review 22(2), 117-137.

Becker, G.S., Murphy, K.M. and Tamura, R., (1994). Human Capital.The University of Chicago Press, U.S.

Benhabib, J. and Spiegel, M. (1994).The Role of Human Capital in Economic Development Evidence from Aggregate Cross-country Data, Journal of Monetary Economics 34(2), 143-173.

Cai, F. (2008). Approaching a Triumphal Span: How Far is China towards Its Lewisian Turing Point,World Institute for Development Economics Research Paper 16(6), 63-80.

Cai, F., Wang, D.W. and Du,Y. (2002). Regional Disparity and Economic Growth in China:The Impact of Labor Market Distortions, China Economic Review13, 197-212.

Chen, B.Z. andFeng, Y. (2000).Determinants of economic growth in China: Private Enterprise, Education, and Openness, China Economic Review 11(1), 1-15.

Chen, G.F. and Hamori, S. (2009). Economic Returns to Schooling in Urban China: OLS and the Instrumental Variables Approach, China Economic Review 20, 143-152.

Demurger, S. (2001).Infrastructure Development and Economic Growth: An Explanation for Regional Disparities in China, Journal of Comparative Economics 29, 95-117.

Fleisher, B.M. and Wang, X.J. (2005). Returns to Schooling in China under Planning and Reform, Journal of Comparative Economics 33, 265-277.

Gordon, R.H. and Li, D.D. (1999).The Effects of Wage Distortions on the transition: Theory and Evidence from China, European Economic Review 43, 163-183.

Griffith, R., Redding S. and Reenen, J.V. (2004). Mapping the Two Faces of R\&D: Productivity Growth in a Panel of OECD Industries, The Review of Economics and Statistics 86(4), 883-895.

Heckman, J.J. and Li, X.S. (2003). Selection Bias, Comparative Advantage and Heterogenous Returns to Education: Evidence from China in 2000, Institute for Labor Market Policy Evaluation Working Paper 17.

Heshmati, A. and Yang, W.S. (2006).Contribution of ICT to the Chinese Economic Growth, Techno-Economics and Policy Program Discussion Paper, Seoul National University.

Hoffman, W.G. (1958). The Growth of Industrial Economies. Manchester University Press, UK.

Hsiao, C.(2001).Analysis of Panel Data.Cambridge University Press, Cambridge, UK.

Kreamer, K.L. and Dedrick, J. (1999). Information Technology and Productivity: 
Results and Policy Implications of Cross-Country Studies, World Institute for Development Economics Research Paper2(99), 1-47.

Konrai, J. (1992).The socialist system. Princeton University Press, Princeton.

Kuznets, S. (1979). Growth and Structural Shifts, Economic Growth and Structural Change in Taiwan: The Postwar Experience of the Republic of China, Cornell University Press, US.

Lin, Y.F, Yao, G. and Yueh, L. (2007).China’s Economic Reforms in the Globalization Era, Globalization and Economic Growth in China.World Scientific Press,Singapore.

Ling, Y. and Lahr, M.L. (2008). Labor Productivity Difference in China 1987-1997: An Interregional Decomposition Analysis, Review of Regional Studies, The State University of New Jersey.

Liu, Z., Hu, F. and Khan, M.S. (1997). Why is China Growing So Fast?, IMF Staff Papers 44(1), 103-121.

Maddison, A. (1987). Growth and Slowdown in Advanced Capitalist economics: Techniques of Quantitative Assessment, Journal of Economic Literature 25(2), 649-698.

Meng Q.X. and Li, M.Z. (2002).New Economy and ICT development in China, Information Economics and Policy 14, 275-295.

Morbey, G.K. and Reithner, R.M. (1990).How R\&D Affects Sales Growth, Productivity and Profitability, Research Technology Management 33(3), 11-15.

Islam, N. (1995). Growth Empirics: A Panel Data Approach, The Quarterly Journal of Economics 110(4), 1127-1170.

Peng, G.H. (2005). The Disparity of Income, TFP and the Convergence Hypothesis in Chinese Provinces, Economic Research Journal 9(3), 24-33

Romer, P.M. (1990)."Human Capital and Growth: Theory and Evidence." Carnegie-Rochester Conference Series on Public Policy, Elsevier 32(1), 251-286.

Sally, R. (2007). China's Trade Policies in Wider Asian Perspective, Globalization and Economic Growth in China.World Scientific Press, Singapore.

Shui, A. and Heshmati, A. (2006). Technical Change and Total Factor Productivity Growth for Chinese Provinces: A Panel Data Analysis, IZA Discussion Paper No.2133.

Solow, R. (1957). Technical Change and the Aggregate Production.Review Economics Statistics 39, 312-320.

Song, L.G. and Yao, Y.D. (2007).The Impact of Privatization on Firm Performance in China”, Globalization and Economic Growth in China.World Scientific Press, Singapore.

Wang, Y. and Yao, Y.D. (2003).Sources of China's Economic Growth 1952-1999: Incorporating Human Capital Accumulation, China Economic Review 14(1), 32-52.

Wei, Y.H. (2000). Investment and Regional Development in Post-Mao China, GeoJournal 51(3), 169-179. 
Weitzman, M. and Kruse, D. (1996).Profit sharing and productivity, The Economic Nature of the Firm, Cambridge University Press.

Wong, T. (2006).Granger Causality Tests among Openness to International Trade, Human Capital Accumulation and Economic Growth in China: 1952-1999,International Economic Journal20(3), 258-302.

Wu, Y.R. (2008).Productivity, Efficiency and Economic Growth in China. Palgrave Macmillan Press, UK.

Yang, L. and Lahr, M. L. (2008).Labor Productivity Difference in China 1987-1997: An Interregional Decomposition Analysis, Review of Region Studies, Rutgers University.

Yi, G., Fan, G. and Li, Y. (2003).A Theoretical Analysis on Economic Growth in China and Total Factor Productivity, Economic Research Journal 8(1), 25-33.

Yue, S.J. and Liu, C.M. (2006).Human Capital Accumulation and Regional Total Factor productivity, Economic Research Journal4(8), 22-44. 
Table 1.Summary Statistics of the Variables

\begin{tabular}{|c|c|c|c|c|c|}
\hline Variable & Definition & Mean & Std.Dev. & Minimum & Maximum \\
\hline GDP & Gross Domestic products & 592285.344 & 566361.536 & 12365.000 & 3202508.361 \\
\hline LABPRO & GDP per labor & 29491.089 & 21903.752 & 5072.706 & 131809.625 \\
\hline LAB & Total labor & 21.870 & 15.159 & 1.234 & 59.488 \\
\hline INV & Investment in Fixed asset & 275107.733 & 273780.273 & 6405.000 & 1591515.886 \\
\hline EDU & Expenditure in education & 20987.850 & 16337.122 & 769.810 & 97504.629 \\
\hline POS & $\begin{array}{l}\text { Volume of post and } \\
\text { telecommunication services }\end{array}$ & 37122.361 & 43380.477 & 500.000 & 346915.552 \\
\hline WAGE & Annual average wage & 172.430 & 78.189 & 69.180 & 487.759 \\
\hline SIND & Share of industry & 0.456 & 0.088 & 0.193 & 0.664 \\
\hline SURB & Share of urban labor & 0.309 & 0.155 & 0.115 & 0.809 \\
\hline SFEM & Female labor participation & 0.371 & 0.038 & 0.106 & 0.586 \\
\hline GLABPRO & Growth in labor productivity & 5.500 & 2.877 & 1.000 & 10.000 \\
\hline GINVLAB & $\begin{array}{l}\text { Growth in fixed asset } \\
\text { investment per labor }\end{array}$ & 0.097 & 0.051 & -0.073 & 0.232 \\
\hline GEDULAB & $\begin{array}{l}\text { Growth of investment in } \\
\text { education per labor }\end{array}$ & 0.176 & 0.117 & -0.127 & 0.648 \\
\hline GPOSLAB & $\begin{array}{l}\text { Growth of post and telecom. } \\
\text { service per labor }\end{array}$ & 0.279 & 0.445 & -0.524 & 5.564 \\
\hline GWAGLAB & $\begin{array}{l}\text { Growth of annual average } \\
\text { wage }\end{array}$ & 0.112 & 0.058 & -0.079 & 0.395 \\
\hline CPI & Consumer Price index & 107.580 & 7.496 & 99.900 & 120.400 \\
\hline
\end{tabular}


Table 2.Fixed Effects Parameter Estimation Results, NT=310 observations.

\begin{tabular}{|c|c|c|c|c|c|c|}
\hline & \multicolumn{2}{|c|}{$\begin{array}{c}\text { Model } 1 \\
\text { Production Function }\end{array}$} & \multicolumn{2}{|c|}{$\begin{array}{c}\text { Model } 2 \\
\text { Labor Productivity } \\
\text { Level }\end{array}$} & \multicolumn{2}{|c|}{$\begin{array}{c}\text { Model } 3 \\
\text { Labor Productivity } \\
\text { Growth Rate }\end{array}$} \\
\hline & Coefficient & Std.Err (1) & Coefficient & Std.Err (1) & Coefficient & Std.Err (1) \\
\hline Constant & $9.254^{* * *}$ & 0.540 & $5.130 * * *$ & 0.547 & 0.052 & 0.049 \\
\hline LnLAB & $0.230 * * *$ & 0.073 & & & & \\
\hline LnINV & $0.165^{* * *}$ & 0.021 & & & & \\
\hline LnEDU & $-0.051^{*}$ & 0.030 & & & & \\
\hline LnPOS & $0.134^{* * *}$ & 0.033 & & & & \\
\hline LnPROLAB & & & $0.032 * * *$ & 0.007 & & \\
\hline LnINVLAB & & & $0.179 * * *$ & 0.019 & & \\
\hline LnEDULAB & & & 0.013 & 0.028 & & \\
\hline LnPOSLAB & & & $0.177^{* * *}$ & 0.031 & & \\
\hline SIND & $0.523^{* * *}$ & 0.100 & $0.220 * * *$ & 0.085 & $0.108 * *$ & 0.045 \\
\hline SURB & $0.234 * *$ & 0.108 & $0.206^{*}$ & 0.113 & $-0.150 * *$ & 0.071 \\
\hline SFEM & 0.062 & 0.048 & 0.012 & 0.071 & 0.020 & 0.040 \\
\hline LnWAGE & & & $0.201^{* * *}$ & 0.054 & & \\
\hline GPROLAB & & & & & $0.011^{* *}$ & 0.006 \\
\hline GINVLAB & & & & & $0.117 * * *$ & 0.023 \\
\hline GEDULAB & & & & & $0.072 * *$ & 0.029 \\
\hline GPOSLAB & & & & & $0.052 * *$ & 0.021 \\
\hline GWAGELAB & & & & & $0.087 * *$ & 0.043 \\
\hline 2000 & -- & -- & -- & -- & -- & -- \\
\hline 2001 & $0.039 * * *$ & 0.014 & -0.021 & 0.015 & $0.029 * * *$ & 0.010 \\
\hline 2002 & $0.094 * * *$ & 0.023 & $-0.037 *$ & 0.022 & $0.032 * *$ & 0.013 \\
\hline 2003 & $0.153^{* * *}$ & 0.030 & -0.036 & 0.027 & $0.050 * * *$ & 0.010 \\
\hline 2004 & $0.219 * * *$ & 0.039 & -0.024 & 0.034 & $0.073^{* * *}$ & 0.010 \\
\hline 2005 & $0.299 * * *$ & 0.048 & -0.003 & 0.040 & $0.066 * * *$ & 0.009 \\
\hline 2006 & $0.363^{* * *}$ & 0.058 & 0.001 & 0.048 & $0.058 * * *$ & 0.010 \\
\hline 2007 & $0.428 * * *$ & 0.066 & 0.009 & 0.056 & $0.070 * * *$ & 0.010 \\
\hline 2008 & $0.500 * * *$ & 0.073 & 0.036 & 0.061 & $0.055^{* * *}$ & 0.010 \\
\hline 2009 & $0.536 * * *$ & 0.082 & 0.011 & 0.066 & 0.008 & 0.012 \\
\hline Beijing & -- & -- & -- & -- & -- & -- \\
\hline Tianjin & $-0.379 * * *$ & 0.095 & $0.140 * * *$ & 0.048 & -0.012 & 0.020 \\
\hline Shanghai & $0.186^{* * *}$ & 0.026 & $0.248 * * *$ & 0.023 & -0.011 & 0.016 \\
\hline Hebei & -0.027 & 0.126 & $-0.309 * * *$ & 0.107 & $-0.083^{* *}$ & 0.040 \\
\hline Liaoning & -0.094 & 0.072 & $-0.168 * *$ & 0.076 & $-0.058 * *$ & 0.027 \\
\hline Jiangsu & $0.387 * * *$ & 0.141 & -0.077 & 0.082 & $-0.065^{* *}$ & 0.033 \\
\hline
\end{tabular}




\begin{tabular}{|c|c|c|c|c|c|c|}
\hline Zhejiang & 0.162 & 0.125 & $-0.259 * * *$ & 0.076 & $-0.070 * *$ & 0.033 \\
\hline Fujian & $-0.175^{* *}$ & 0.072 & $-0.230 * * *$ & 0.084 & $-0.077 * *$ & 0.035 \\
\hline Shandong & $0.330 * *$ & 0.161 & $-0.180 *$ & 0.102 & $-0.063 *$ & 0.036 \\
\hline Guangdong & $0.481^{* * *}$ & 0.162 & $-0.159 * *$ & 0.069 & $-0.064 * *$ & 0.030 \\
\hline Guangxi & $-0.538 * * *$ & 0.097 & $-0.652 * * *$ & 0.108 & $-0.070 *$ & 0.040 \\
\hline Hainan & $-1.210^{* * *}$ & 0.131 & $-0.407 * * *$ & 0.084 & $-0.056^{*}$ & 0.030 \\
\hline Eastern Avg. & -0.076 & & -0.271 & & -0.067 & \\
\hline Shanxi & $-0.553^{* * *}$ & 0.060 & $-0.398 * * *$ & 0.094 & $-0.068 * *$ & 0.034 \\
\hline Inner Mongolia & $-0.504^{* * *}$ & 0.058 & $-0.210^{* *}$ & 0.090 & -0.018 & 0.029 \\
\hline Jilin & $-0.523^{* * *}$ & 0.044 & $-0.278 * * *$ & 0.083 & -0.037 & 0.028 \\
\hline Heilongjiang & $-0.348^{* * *}$ & 0.056 & $-0.289 * * *$ & 0.084 & $-0.063^{* *}$ & 0.027 \\
\hline Anhui & $-0.410 * * *$ & 0.120 & $-0.634 * * *$ & 0.115 & $-0.090 * *$ & 0.040 \\
\hline Jiangxi & $-0.587 * * *$ & 0.082 & $-0.540 * * *$ & 0.110 & $-0.087 * *$ & 0.037 \\
\hline Henan & -0.076 & 0.162 & $-0.538 * * *$ & 0.117 & $-0.078 *$ & 0.041 \\
\hline Hubei & $-0.240 * *$ & 0.098 & $-0.378 * * *$ & 0.099 & $-0.065^{*}$ & 0.034 \\
\hline Hunan & -0.242 & 0.124 & $-0.526 * * *$ & 0.106 & $-0.071 *$ & 0.039 \\
\hline Middle Avg. & -0.387 & & -0.421 & & -0.064 & \\
\hline Chongqing & $-0.753^{* * *}$ & 0.073 & $-0.666 * * *$ & 0.103 & $-0.078 * *$ & 0.038 \\
\hline Sichuan & $-0.257 * * *$ & 0.146 & $-0.662 * * *$ & 0.109 & $-0.077^{*}$ & 0.040 \\
\hline Guizhou & $-1.091^{* * *}$ & 0.087 & $-1.039 * * *$ & 0.116 & $-0.088^{* *}$ & 0.044 \\
\hline Yunnan & $-0.684 * * *$ & 0.093 & $-0.781^{* * *}$ & 0.107 & $-0.091^{* *}$ & 0.040 \\
\hline Xizang & $-1.981^{* * *}$ & 0.235 & $-0.791^{* * *}$ & 0.084 & $-0.063^{*}$ & 0.037 \\
\hline Shaanxi & $-0.645^{* * *}$ & 0.073 & $-0.636 * * *$ & 0.097 & -0.051 & 0.035 \\
\hline Gansu & $-0.992 * * *$ & 0.070 & $-0.728 * * *$ & 0.107 & $-0.087^{* *}$ & 0.038 \\
\hline Qinghai & $-1.681^{* * *}$ & 0.181 & $-0.672 * * *$ & 0.090 & $-0.065^{* *}$ & 0.033 \\
\hline Ningxia & $-1.619 * * *$ & 0.162 & $-0.653^{* * *}$ & 0.090 & $-0.054^{*}$ & 0.032 \\
\hline Xinjiang & $-0.753^{* * *}$ & 0.058 & $-0.365^{* * *}$ & 0.069 & $-0.046^{* *}$ & 0.023 \\
\hline Western Avg. & -1.046 & & -0.700 & & -0.070 & \\
\hline Adjusted $\mathrm{R}^{2}$ & 0.9986 & & 0.9960 & & 0.7376 & \\
\hline
\end{tabular}

Notes: Robust standard errors. Total number of observations $=310$, Significance level: ${ }^{*} \mathrm{p}<0.1 ;{ }^{* *} \mathrm{p}<0.05$;

$* * * \mathrm{p}<0.01$ 